\title{
7. Insights from Friedrich Hayek
}

\section{Bruce Caldwell ${ }^{1}$}

Many people first heard about Friedrich Hayek last summer when The Road to Serfdom (1944) reached number one on Amazon.com. It stayed there for about ten days, stayed in the top 100 for two months, and was still in the top 300 a year later. This book was published in 1944, and it is pretty unusual that a book written so long ago would suddenly rocket to number one on Amazon.com. Why did this happen? Commentator Glenn Beck held up a copy of The Road to Serfdom on one of his shows and said: 'This book is like a Mike Tyson right jab to the jaw of socialism.' Then he urged viewers to go out and buy it - and people bought it in droves.

If you are a YouTube watcher and you like economics you might have seen the two rap videos in which actors playing Hayek and John Maynard Keynes debate each other. ${ }^{2}$ Then there was a real debate that recently took place at the London School of Economics with George Selgin versus Lord Skidelsky, who is the biographer of Keynes (Skidelsky, 2005). These Keynes/Hayek debates are one reason that 
people have become much more aware of Hayek recently.

I am interested in Hayek because I am interested in the development of economics in the twentieth century. That makes Hayek an ideal person to study, because his life was contemporaneous with the twentieth century. He was born in 1899 in Vienna and died in 1992. Hayek fought in World War I and then attended the University of Vienna. While at the University of Vienna he created a discussion group that included Oscar Morgenstern, who was one of the co-developers of game theory. If you study microeconomics, you probably have run into some of his legacy, in terms of the game theoretical constructs that you use. During this period he also began working alongside Ludwig von Mises, who quickly became his mentor. Hayek and Mises are now viewed as the most prominent Austrian economists of the twentieth century.

Hayek took a trip to the United States to see what was going on here after graduating and sat in on Wesley Clair Mitchell's seminar on the history of economics at Columbia University. Mitchell was one of the most important Institutional Economists, a founding father of the school of thought indigenous to America that challenged mainstream economics. Thorstein Veblen was another prominent member of this school.

After Hayek returned to Vienna, and got married, he received an invitation to the London School of Economics to give some lectures. On the basis of this he landed a job at the London School 
of Economics. Immediately he got embroiled in a conflict with John Maynard Keynes about their respective theories of how a monetary economy works and why it sometimes does not work. Their intellectual battles took place through professional journals and also in face-to-face conversations, because they were all right there together. Keynes was at Cambridge, which is only about 60 miles from London.

While Hayek was at LSE he engaged in battles with lots of other people as well. He helped bring to the London School of Economics Karl Popper, who is certainly one of the most important philosophers of science who is very well known outside of the philosophy of science - the father of falsificationism.

After World War II Hayek co-founded the Mont Pèlerin Society, which aimed to rejuvenate interest in classical liberalism. He ultimately took a job at the University of Chicago, though not in the Economics Department, but at the Committee on Social Thought. But he was basically there at the founding of what came to be known as the Chicago School of Economics.

So Hayek was an economist who ended up being at the right place at the right time throughout his career. He stayed at Chicago through the middle of the 1960s and was awarded the Nobel Prize in 1974 with Gunnar Myrdal. Myrdal, a Swedish economist, was Hayek's ideological opposite. If you think of Hayek as being on the right, Myrdal was on the left. It must be said, neither one was very 
happy about the split prize. Each of them thought that this was some sort of ideological statement by the Prize Committee just simply to kind of have a little balance. And neither one thought much of that. They went on record, discreetly but certainly on record, as not liking the split award.

Now let us try to understand Hayek's most important contributions to economics. I have dedicated almost 25 years of my life to that subject and still do not feel I have figured out all of Hayek's ideas, because he wrote on so many different subjects.

Hayek started out as a monetary economist, trying to work out a model of a capital-using monetary economy. He worked on this for almost 15 years, making some important contributions. Ultimately, though, I think he failed to accomplish all that he wanted to do in terms of this kind of macroeconomic theory.

He is well known for his critique of socialism. That is why he has gotten such attention recently. And in the process of making that critique he came up with some very interesting ideas about knowledge and how markets are a mechanism for coordinating dispersed knowledge. I will return to this later.

Hayek had a project during and after World War II that was extremely productive, with ideas going in lots of different directions. This is the Abuse of Reason project. The Road to Serfdom is one of the pieces that came out of it, as was a book in psychology titled The Sensory Order (1952). I had 
to read The Sensory Order three times before I had any sense of what was going on in the book. Ultimately it is an extremely important book in terms of the development of his thought, and also for his contributions to theoretical psychology. What is the best way to study social phenomena? Hayek made an argument against what he called 'scientism', the attempt to use methods of the natural sciences or methods that have been successful in other areas in the social sciences. He argued that this often misleads us into thinking we can do more in the social sciences than we can.

Then Hayek turned to political philosophy. His two biggest books in this area, The Constitution of Liberty (1960) and Law, Legislation and Liberty (1973-79), are fundamental contributions, I think, to the revival of classical liberalism - liberalism in the nineteenth-century sense of the word.

$\mathrm{He}$ also wrote on spontaneous orders and complex phenomena; arguing that many economic phenomena are in fact examples of complex phenomena, for which we have limited ability to make predictions other than what he called pattern predictions. So he wrote a lot about the limitations of knowledge and also how markets are able to coordinate the use of knowledge.

Let me turn from this general overview of Hayek's career and discuss some of his important insights for today. He was intellectually active in the 1940s and '50s. Many people would say some of his most important contributions came in the 1930s. What would someone whose seminal 
works were written over half a century ago be able to tell us about the sort of economic environment that we currently find ourselves in?

Let me preface these remarks with an important caveat. Hayek was no policy wonk. He would not say that if you want to have the appropriate regulations to avoid moral hazard you need to set up regulation $X$ in this particular way. He was no Milton Friedman. He did not come out with lots of details about specific policies. Instead, he tried to understand things in a philosophical kind of 'general principles' way, and those are the kinds of ideas that he developed.

I will argue, nonetheless, that these insights are quite important, that these fundamental ideas are, in fact, things that we have often lost sight of. He made these general arguments as he lived through the Great Depression, two World Wars and the Cold War. So he might be worth listening to.

The first important idea of Hayek is something almost everyone already knows - money is a very important thing. It facilitates trade. It allows trade to continue and expand when you have the division of labor. As Adam Smith told us, the division of labor is only limited by the extent of the market. Money facilitates trade and allows that market to get bigger. It is one of the most important things that have led to the increase in the 'wealth of nations', as Smith might put it.

Unfortunately, Hayek's next important point is that the business cycle is a necessary and unavoidable concomitant of a market-based, money-using 
economy. Market economies that use money have business cycles. That is his fundamental point. You cannot get around it. They are going to happen. It seems around 2005 and 2006 that a lot of people thought that the business cycle was never going to happen again; that it was banished forever; that we had figured out how to avoid economic downturns. Hayek would not have shared this view. He would always say: just wait a little bit.

The way Hayek put it is that money is the loose joint'. Money is the loose joint that creates the possibility of the cycle. The Austrian theory of the business cycle, which Hayek held, sheds some light on certain aspects of the recent problems that we have had, particularly in terms of the Fed's interest rate policy and its effects on the housing sector. In the Austrian vision a business cycle is generated when interest rates are held too low for too long. Discussions about Fed policy in the run-up to the recent crisis have frequently pointed this out. What happens if interest rates are held for too low too long? In the Austrian terminology, 'malinvestments' take place. People undertake investments that they would not have undertaken otherwise. And as time goes on at some point people realize the only reason that we undertook these was because of the very low interest rate regime, but we are not actually going to be able to sell the goods that we are producing nor those we will be able to produce in the future due to these investments. At that point there is a pull-back, and that generates the downturn in the business cycle. 
Too many investment projects get started that cannot ultimately be sustained.

The Austrians are very good on why cycles get started. Where they really are unpopular is what they say next. They say that you have just got to let things work themselves out; once the cycle has happened there is not much you can do.

There is a little bit of debate about whether Hayek might have said that if deflation gets started it may be advisable to have the monetary authority stimulate. Sometimes Hayek said that. But he did not really say it right in the heart of the Great Depression. So I think it is a fair debate as to what his views were. He did say in the 1970s - when economist Gottfried Haberler kept pressing him and pressing him - okay, okay, yes, they can; they can use monetary policy to offset a severe deflation that takes place. But in general, his idea was once you have got the recession, the recession is actually the economy coming back to equilibrium, if you will. And you have just got to let it continue to come back to equilibrium. In particular, if you try to stimulate demand you can end up setting up problems that are as bad as the ones of the original downturn.

Some things that happened during the recent downturn seem to be examples of this. Consider the automobile industry in late December, 2008. GMAC, which is the lending arm of General Motors, was given a $\$ 6$ billion bailout. This seems like a trivial amount of money in the light of subsequent bailouts, but at the time this was a big deal. The day after the bailout was announced, 
I was driving to work and heard on the radio advertisements saying that GMAC was now providing low interest rate loans. In fact, they were zero interest rate loans. And they were lowering their minimum requirements for credit scores from 700 to 621 . (For some perspective, the subprime designation applies to loan applicants with credit scores of 660 and below.) So they were actually saying, we will give a zero interest loan to almost anyone who wants to buy a car even if their credit rating is below subprime.

A second example, in housing there was a tax credit carrying a maximum value of $\$ 8,000$ offered by the federal government for first-time home buyers in 2009 (and later extended). The idea, presumably - this shows you the unintended consequences - was that these first-time home buyers would go out and start buying up the glut of homes that had been produced by the low interest rate policy. Instead, there was a mini-boom in the housing industry - because a lot of the houses that were on the market were not the right size for first-time home buyers. The policy, which was an attempt to get rid of some of those unsold homes, in fact led to further construction.

Both of these are examples of how perpetuating a low interest rate regime in trying to overcome the cycle can in fact perpetuate malinvestment, the Austrian view of what happens. There is also a fear of setting up inflation down the road. That is another idea that comes through with Hayek and the Austrian business cycle theory. 
So what did Hayek think about government intervention? Investor George Soros says Hayek was a market fundamentalist - and that must mean that he just does not believe in any kind of economic intervention. Philip Mirowski, a historian of economic thought, says he was a neoliberal, and that neoliberals want to use the power of government to protect corporations. So Mirowski says Hayek was in favor of big government helping out business. If you go to the Mises Institute's website at mises.org and read the writings of Walter Block and HansHermann Hoppe, Hayek is described as a social democrat. So there are a wide range of perspectives on him.

Clearly, Hayek was not in favor of there being no government. He was not a foe of government. Hayek felt that some regulation is necessary. He was not opposed to all regulation. ${ }^{3}$ The sort of regulation or 'planning' that Hayek favored was a general system of rules. And this general system of rules would be rules that would best enable individuals to carry out their own plans. Here is the way he put it. We can 'plan' - and he put plan in scare quotes, because he knew it was kind of a scary word - a system of general rules equally applicable to all people, intended to be permanent, which provides an institutional framework within which decisions about what to do and how to earn a living are left up to individuals. In other words, we can plan a system in which individual initiative is given the widest possible scope and 
the best opportunity to bring about effective coordination of individual effort.

In The Constitution of Liberty and some of his other writings, he laid out in general terms the characteristics of the sorts of institutions that he meant. To summarize it very, very briefly, this would include a market system within a democracy, with a system of well-defined, enforced and transferable property rights, with individual rights protected by a strong constitution, operating under the rule of law. He wanted laws that are stable, predictable and equally applied. And if you look at the recent writings of the New Institutional Economics, people like Douglass North, Ronald Coase, and Oliver Williamson - and also some experimental economists like Vernon Smith - all of them credit Hayek for emphasizing the importance of institutions, because these economists' writings examine how institutions affect people's behavior. If you get the institutions right there is a much better chance of getting society working in a good way. It is not just economics; it is economic institutions embedded in a host of other social, cultural, moral institutions.

Robert Mugabe's Zimbabwe demonstrates the importance of these ideas. Zimbabwe used to be the bread basket of Africa. Fifteen years ago it was a net exporter of food. Over the last 15 years, all the general conditions that I just discussed were negated in Zimbabwe. The rule of law disappeared. Judges were intimidated. There was democracy in name only. Property rights were 
obliterated in many cases. As a result, the economy collapsed and hyperinflation ensued. Negate each one of Hayek's desired conditions and you end up with a society that is nonfunctional.

So Hayek believed in a certain framework, a legal framework, a set of institutions in which a society can flourish. But certain types of intervention in the economy, what he called 'legislation', are fraught with problems and will make matters worse. He was a harsh critic of central planning. That is what he was most famous for. This is what The Road to Serfdom and some of his earlier essays on socialism were all about. But he was also talking about other sorts of regulation that afflict a mixed economy. He pointed out many dangers. One of his points is that regulation - attempts to constrain markets - is often well intentioned; but is often bound to fail because regulation cannot keep pace with market innovation. Regulators are looking at the last crisis and are saying: What should we have had in place to avoid that last crisis? You are always regulating for the last crisis. You are not taking into account the market innovations that are going to set up the next crisis. This is one of the reasons he thinks crises are inevitable. It is really hard to anticipate what sorts of changes are going to be taking place in a market system. You are always playing catch-up with regulation. Entrepreneurs are forward looking. Regulators are of necessity backward looking.

A second point is that regulation creates uncertainty. Hayek put it this way in The Road to 
Serfdom: the more the state plans, the more difficult it is for individuals to plan. We can see this in the recent crisis. In 2008 when the Troubled Asset Relief Program (TARP) was being considered by Congress, there were news analysts and political pronouncement warning that if we do not pass this bill the entire financial system would be going down the tubes. People heard this and they wondered whether the bill would pass. And they wondered - if they do pass it, what's going to happen next? As a result of the political uncertainty, there was widespread pulling back in the economy. Imagine yourself as a small business owner, as a homeowner, as somebody ready to buy a car. You see a certain plan under debate and wonder: Well, are they going to rescue the home owners? Or are they not? Is the Fed going to step in and rescue Fannie Mae or not? What is going to be happening to these government agencies? What is going to happen to the banks? You do not know what is going to happen. Politics is creating additional uncertainty. And what happens when you do not know what is going to happen? Most people just stop. It seems like that kind of stopping happened a lot in this latest crisis. So the difficulty of making decisions increases in an environment of uncertainty in which the government as an actor creates part of that uncertainty.

Hayek argued that even well-intentioned legislation can be hijacked by strong special interests. I do not think I need to give many examples here, because every one of you can come up with ten 
of them. Think of ethanol. In addition, some legislation simply encourages bad behavior, what economists called moral hazard and misaligned incentives. This would be the Greenspan put; the idea that since the financial system is going to be rescued, we do not need to worry about it or play it safe. There is Juvenal's question: Who is going to watch the regulators? Who is going to regulate the regulators? Sure, we may have regulation in place, but think of the Keating Five as an example of where a regulation can go awry.

And finally, most importantly, warned Hayek, legislation endangers liberty. Regulation is basically a constraint on individual behavior. Hayek understood that an economy needs a certain amount of, if you will, regulation; but that many sorts of regulation can in fact end up harming us.

His next, and perhaps most important, insight is that the economy is an example of an essentially complex phenomenon, for which precise forecasting is impossible. Rational economic policy typically depends on being able to forecast what is going to happen if you undertake certain policies. It is hard enough to assess past events. An example would be to assess what happened when the recent stimulus package was passed and started to operate. The official administration forecast was that if we did not pass the stimulus package unemployment would rise from about 5 percent to 8 percent. Then the stimulus package was passed. And immediately unemployment went to 9 , and then 10 percent. So much for the 
forecast. The forecast was offered in an attempt to get stimulative action enacted, but the forecast was wholly wrong.

So what was the response to the failed forecast and rising unemployment rate? Paul Krugman's response was that it was not enough; we needed a larger stimulus package; that is why it did not work. The Republicans said: You used the wrong stimulus package; you should not have increased government spending; you should have cut taxes. Larry Summers may have been the only person who claimed that we got it just right; the stimulus package was just the right size; it is all going to work out. Every commentator seemed to have a different opinion.

The point is that we just do not know. We just do not know what should have been done; and what would have happened if we had not passed the stimulus. We are dealing with an enormously complex phenomenon. And to pretend that we know what to do is amazing hubris. Anyone who is studying economics should immediately discount anyone who makes predictions like this with any kind of confidence.

So, as Hayek emphasized, this knowledge problem is a huge obstacle to rational policymaking. And if you join it together with some of the political and other economic obstacles that are in the way of making rational policy, your hopes of getting good policy out of Washington or any other government has to be pretty slim.

Let me just point out a few of these additional 
problems. There are lags in policymaking between the time a problem is recognized in the economy, and the time the policy gets formulated, and the time the policy starts taking effect. If these lags exist you can have a policy that is planned at one point, and by the time it takes effect the economy is in a different place so the policy has a destabilizing effect.

Moreover, the political process sometimes subordinates the stabilization of the economy to other government policy goals on the one hand, or simply to the self-interested special interest behavior of Congress - following either their own interests or the interests of the clients that they represent.

Tax cuts, despite Republican rhetoric, sometimes get saved rather than spent, at which times they have very little stimulative impact. In a like manner, increases in government spending, despite Democratic rhetoric, if they are viewed as temporary, if they are going to go away soon, often do not have much stimulative effect either. The multiplier is very small. No one knows how large it will be in any particular case. This puts business in a hard place. As a business person you never want to be left behind. If the economy is starting to take off you want to participate in that. But if you are worried about it kicking off you certainly do not want to start up too early. So if you think either a tax cut or a stimulative package is a temporary thing that is going to run out, your confidence in this actually having any 
effect is much lower, and as a result the impact is much lower.

We are also seeing the old 'you cannot push on a string' phenomenon today. Interest rates have been near zero, if not negative in some places, for a couple of years. But if people are afraid to lend to firms and firms do not want to borrow it does not do anything.

Does all this mean you cannot get policy right? No. You can actually get policy perfectly right sometimes. And other times it does not work. Hayek's point - and this is a general principle that comes out of his idea of the economy being an example of a complex phenomenon - is you just really cannot tell in advance. It may work. It may not work. But it is hubris to think that you are going to be able to just mechanically plan out these things, make precise predictions, when you are dealing with something as complex as an economy.

Here is something that will make all of the economic students and their professors happy. Hayek's next point is that basic economic reasoning captures what we can know and say about the essentially complex phenomenon that we call the economy. When Hayek wrote about complex systems he often took examples from things like biology and fields other than the social sciences, which is frustrating to economists. But recently I have been spending more time in the archives and I have found some material he did not publish, called 'The Economic Calculus'. It basically was 
intro economics. Hayek said that when you are dealing with complex phenomena there are certain things that have been identified about how an economy works in general, identified over a period of about 300 years, which in recent times have been formalized by very simple concepts like demand and supply diagrams and production possibility frontiers. These concepts actually shed a lot of light on how the complex system that we call an economy works.

These tools allow us to talk about the fundamental fact of scarcity; the choices that scarcity makes necessary; the costs of choice; ways to push back against scarcity; at which point the notions of the division of labor, specialization, comparative advantage, the productivity of capital, human capital and physical capital, and the gains from trade are all introduced. All these are phrases that are familiar after you have had Intro to Economics. But all of them are important economic concepts. And if you add to them the concepts of elasticity of demand and supply and some basic intuitions about market structures you can explain a lot about the world. I have taught Intro to Microeconomics for decades. And it is always amazing and gratifying to me how far you can take a person with just one course in terms of their understanding about how the world works. It does not mean that you are going to be able to make precise predictions. But you are going to understand how markets work, and it is quite useful in that way. 
We forget this, I think, at our risk. I had a conversation one time with a technically very well trained game theorist about cartels. I had mentioned three conditions that must be met for a cartel to be able to continue to keep prices high through time - a large share of total output, no close substitutes, and the ability to catch cheaters on the agreement. I said that I do not worry about cartels much because it is hard to maintain those three conditions. You can do it for a short amount of time, but typically they break down very quickly. Game theorists study situations in which small numbers of people interact - and cartel behavior is one thing that is dear to their heart. But this person had never even heard of these three conditions and looked at me like I was from Mars. It did not compute. Yet, it is probably the most important thing that you can understand about how these sorts of markets work or fail to work.

The Principles course, if well taught, is probably the most important course that anyone who wants to understand how a market system works can take. And many of the most compelling examples in a Principles course have to do with bad policy responses. And most of these involve some sort of price fixing. It is interesting that we cannot make very good policy predictions except when you fix prices. And then we can make real good predictions about what is going to happen. Just think of the examples that you have probably seen: agricultural price supports, rent controls, 
comparable worth policies, price ceilings on gasoline or natural gas, laws prohibiting the resale of concert tickets. All of these are examples of cases when someone has a good idea of what they want to accomplish; they have good intentions; and in fact the policies end up having very bad results. They do not deliver the result that you are attempting to achieve, and in fact have malignant outcomes on top of it.

Such a course should also emphasize appropriate policy responses. Think about the environmentalist movement. My heart cries out as someone who cares about the environment that more people do not have an idea what free market environmentalism is about and how well-defined property rights can in fact help solve many of the problems that exist.

Let me close with two big insights, the basic Hayekian insight and then a fundamental public choice idea. The basic Hayekian insight is how freely-adjusting market prices help solve what he called the knowledge problem and enhance social cooperation. If you read just one article by Hayek, read 'The Use of Knowledge in Society' (1945). Economic models often assume that people have a given set of tastes, given incomes, and face given cost conditions - and that all of this information is known to everyone. Hayek said that if this was the way the world actually worked we could have a social planner, we could have a central planner; it would work perfectly. He says this at the beginning of the article. Friedrich Hayek says socialism 
would work if these conditions were met. But then he explains that the real problem is these conditions are never met. In the real world you have got dispersed knowledge. Knowledge is dispersed among billions of people. Each person has a bit of localized knowledge. Each person is working in a firm; each person is a consumer. Whichever hat you have on, you have bits of localized knowledge, what Hayek called 'knowledge of the particular circumstances of time and place'. Some of that knowledge is tacit. You cannot even tell how you know that yes, this is a good time to buy in this market after you have worked in it for 20 years, or this is a good time to hedge your bets. In the real world it is also true that people think they know stuff that is wrong. People make mistakes constantly. Errors are constantly being made.

So the question that must be solved in constructing a rational economic order in such a world is how we can use the knowledge that is dispersed among these billions of people so as to achieve some level of social coordination and cooperation. It is all about cooperating with millions of other people.

Hayek's answer was that a market system with freely-adjusting, market-determined prices - when embedded within an appropriate institutional framework - is a marvelous (yes, he used the word marvelous) mechanism for coordinating human action. It is a complex, adaptive system. You may not know what is causing a price to change. It is not important that you do. Sometimes 
you may ask: What is happening to cause this price to change? But usually, in making day-today decisions, you and millions of other people are just reacting to price changes and economizing at the margin. Increasing or decreasing what you do a little. And every one of those actions gets fed into the system. So you are reacting to this array of prices that you confront, just as are millions of other people. And all of those actions create the array of prices. That is what he meant by complex phenomena. And people react in reasonable ways - demand curves slope downwards; supply curves slope upwards. They react in ways that in fact economize on scarce resources - even if they are not trying to. It is just simply by individual actions that this is what occurs.

The actions of market participants are simultaneously price determined and price determining. Bad decisions and mistakes are constantly made. But in a market system such errors are opportunities for others. And this is why they get eliminated. If you think about other systems, the ability to get rid of mistakes is much more difficult. So that is the basic Hayekian idea.

Two big mistakes are first to fail to recognize that the market system is able to do these things. And second, to think that you have got more knowledge than you do when you try to intervene. Because typically if you think about the proposed interventions they almost always seem to say, if we knew all this we could arrange these things so these inefficiencies and inequities would 
not occur. The question should always be: How would you know? What sort of knowledge do you need to do that?

Now, here is the basic public choice insight. It is not that Hayek and the Austrian School hate government. It is just that they think that often government is not going to do what it promises to do. This leans on insights from Public Choice Economics. I will just name a few of the insights. Voters are rationally ignorant - because each voter knows that his or her single vote will have very little impact on the outcome of an election, they have much less interest in finding out all of the information. You can join this with Bryan Caplan's (2007) insight that usually when people vote they just vote for things that make them feel good. I am a real American, so I am going to keep out those foreign workers. I like poor people, so I am going to vote for the minimum wage. They have little knowledge about the ultimate impacts of these various policies, but simply vote for what makes them feel good.

Politicians seeing this also respond rationally. They are going to think, 'If I am going to be elected I have got to give people the policies that they want.' So, if voters are not thinking things through, I will give them the bad policies they've asked for. Caplan's The Myth of the Rational Voter is worth a look.

It is not only that bad policy gets made this way, but there is also the effect of concentrated benefits and diffuse costs on policymaking. Established special interests can benefit from certain policies 
when the benefits are concentrated, while the costs are spread across all of society - most of which is not paying any attention. Many policies are instituted like that. And once they are in place they are quite difficult to get rid of.

Bureaucrats - this is William Niskanen's big point - have an incentive to maximize the size of bureaucracy under their control. James Buchanan and Richard Wagner in their wonderfully titled book, Democracy in Deficit (1977), argue that democratic politics leads naturally to deficits. Politicians are always claiming that they are going to constrain these deficits, but if they do constrain deficits, it hurts them politically, and they do not get re-elected. There are not many politicians that run on a platform of: vote for me; I will balance the budget by raising your taxes.

The final idea of public choice economics is rent-seeking - the idea that you can make money by competing; but you can also make money by getting the government to restrict your competition and grant you some sort of monopoly rights over a particular industry.

What I have just described is what I call the Austrian/public choice one-two punch. (I started out with Mike Tyson, so I may as well finish with a pugilistic metaphor.) We usually do not have the necessary knowledge to intervene effectively. And the political process is such that even if we did we still likely would get bad policy. And yet the government sector continues to grow.

This is why Hayek, the Austrians and many 
public choice theorists favor smaller government. It is not that they hate government. They just think that it is often ineffective. Especially in today's environment, these are insights that I think bear repetition.

\section{Notes}

1. This talk was given at Wake Forest University on September 13, 2011. Parts of the chapter are similar to another article I have published: 'Ten (Mostly) Austrian Insights for These Trying Times', in Joseph Postell and Bradley C.S. Watson (eds), Rediscovering Political Economy, Lanham, MD: Lexington Books (2011), pp.107-132.

2. "Fear the Boom and Bust" a Hayek vs. Keynes Rap Anthem' at http://www.youtube.com/watch?v= d0nERTFo-Sk has been viewed over three million times since January 23, 2010 and 'Fight of the Century: Keynes vs. Hayek Round Two' at http://www.youtube.com/ watch?v=GTQnarzmTOc has been viewed nearly two million times since April 27, 2011.

3. I use the word 'regulation' but in the 1930s it was more common to talk about 'planning'. In the last few years many pundits have said that what we need is more regulation. And just as was the case in the 1930s, they rarely say exactly what that means.

\section{References}

Buchanan, J.M. and R.E. Wagner (1977), Deomcracy in Deficit: The Political Legacy of Lord Keynes, New York: Academic Press.

Caplan, B. (2007), The Myth of the Rational Voter: Why Democracies Choose Bad Policies, Princeton: Princeton University Press.

Hayek, F.A. (1944), The Road to Serfdom, Chicago: University of Chicago Press.

Hayek, F.A. (1945), 'The Use of Knowledge in Society', American Economic Review, 35 (4), 519-530. 
Hayek, F.A. (1952), The Sensory Order: An Inquiry into the Foundations of Theoretical Psychology, London: Routledge \& Kegan Paul.

Hayek, F.A. (1960), The Constitution of Liberty, Chicago: University of Chicago Press.

Hayek, F.A. (1973-79), Law, Legislation and Liberty, Chicago: University of Chicago Press.

Skidelsky, R.J.A. (2005), John Maynard Keynes, 1883-1946: Economist, Philosopher, Statesman, New York: Penguin. 